\title{
Working
}

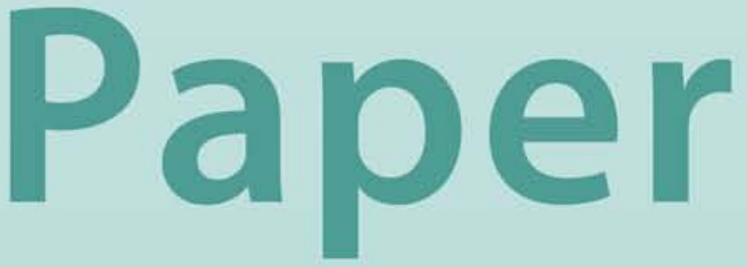




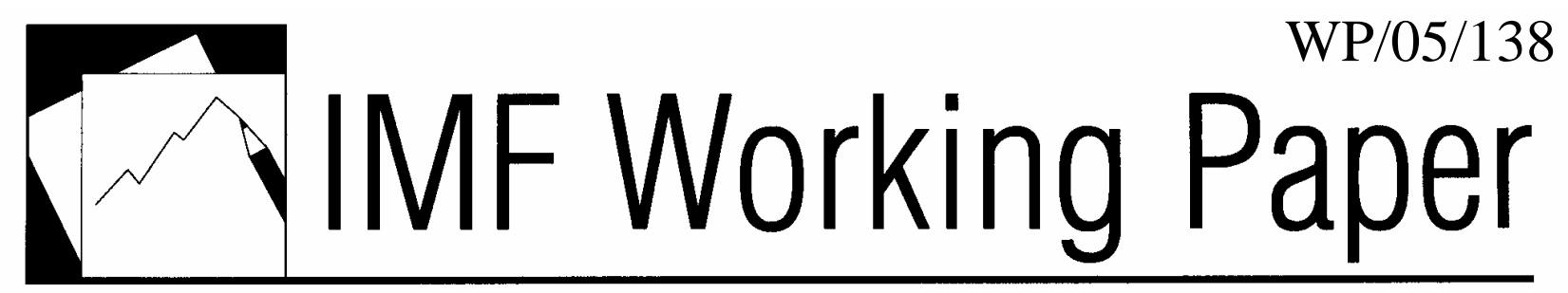

\section{U.S. Tax Reform: An Overview of the Current Debate and Policy Options}

Thomas Dalsgaard 


\title{
IMF Working Paper
}

Fiscal Affairs Department

\section{U.S. Tax Reform: An Overview of the Current Debate and Policy Options}

\author{
Prepared by Thomas Dalsgaard ${ }^{1}$ \\ Authorized for distribution by Michael Keen
}

July 2005

\begin{abstract}

\section{This Working Paper should not be reported as representing the views of the IMF.} The views expressed in this Working Paper are those of the author(s) and do not necessarily represent those of the IMF or IMF policy. Working Papers describe research in progress by the author(s) and are published to elicit comments and to further debate.
\end{abstract}

In the context of the current tax policy debate in the United States, this paper reviews and discusses some of the main recurrent themes, as well as some of the most important tax reform proposals put forward over the past two decades. It finds that although there seems to be widespread agreement that the current tax system is too complex, unfair, and distortionary, little or no consensus exists on how best to improve it.

JEL Classification Numbers: H20, H21, H24, H25

Keywords: Consumption tax; income tax; flat tax; national retail sales tax; dual income tax; book tax, alternative minimum tax; estate tax

Author(s) E-Mail Address: tdalsgaard@imf.org

\footnotetext{
${ }^{1}$ The author is a senior economist with the IMF’s Tax Policy Division. Helpful comments from Len Burman, Emil Sunley, Michael Keen, Russell Krelove, Dennis Botman, and seminar participants are gratefully acknowledged.
} 


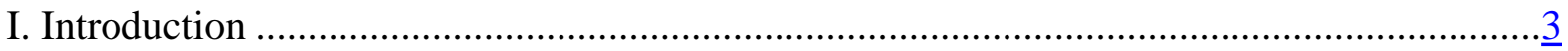

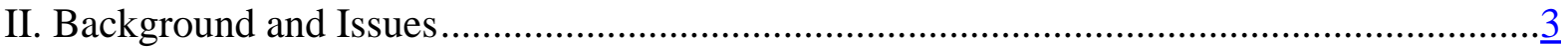

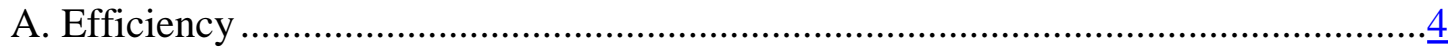

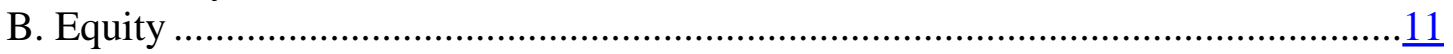

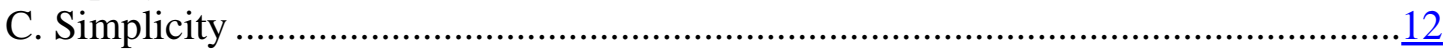

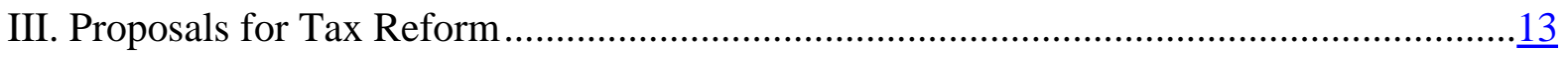

A. Treasury “Option 5” (Incremental Adjustment) …........................................ 15

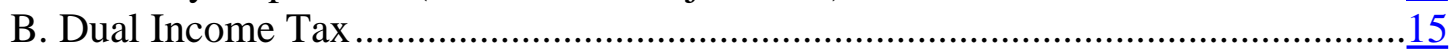

C. Combined VAT and Income Tax ............................................................... $\frac{16}{17}$

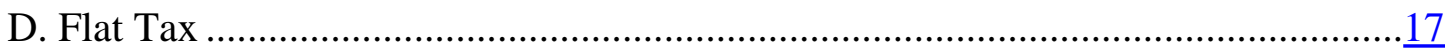

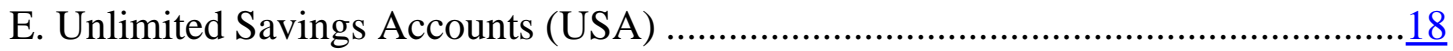

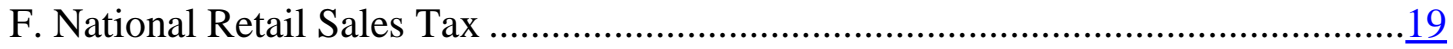

IV. International Aspects .................................................................................... 20

A. Foreign Direct Investment and Tax Treaties.................................................. $\frac{20}{21}$

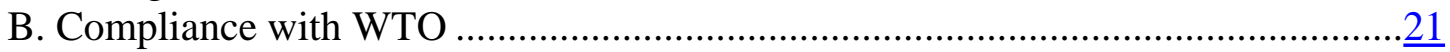

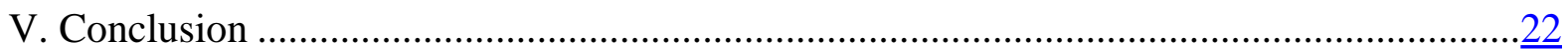

Tables

1. Selected Deductions, Exemptions, and Credits in the U.S. Personal Income Tax System.... $\underline{9}$

2. Key Elements of Six Reform Proposals (Revenue Neutral Under Current Law)................14

Boxes

1. The Tax Cuts of 2001-2004 …..................................................................................

2. U.S. Tax Expressions-A Mini-Glossary _...............................................................

Appendices

I. Economic Similarities and Differences Among Tax Reform Proposals ...........................28

II. The Marriage Penalty-An Example ........................................................................ 29

Appendix Table

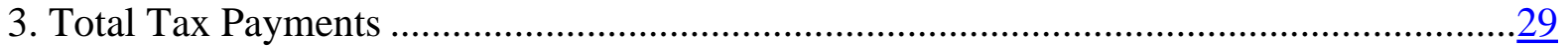

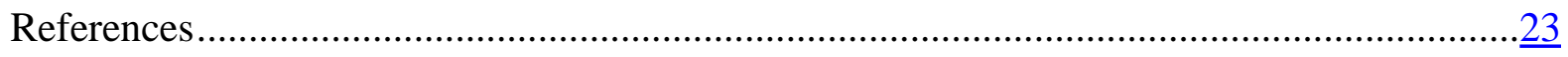




\section{INTRODUCTION}

The tax debate in the United States, already lively, gained further momentum with the appointment in January 2005 of an Advisory Panel on Tax Reform. The panel, headed by former Senators Connie Mack and John Breaux, is due to report its findings and recommendations to the Secretary of the Treasury by the end of July 2005. The tax debate is further spurred by the ongoing Social Security discussion, which, at some point, is likely to have ramifications for tax policy as well.

For those who do not follow it closely, this debate can easily become complex, confusing, and jargon-laden. The purpose of this paper is to ease these entry barriers to participating in and understanding the debate, which will soon move to center stage, by providing a brief overview of the main issues at stake and the major reform proposals under discussion. It does not attempt to predict the likely recommendations of the panel. ${ }^{2}$ Rather, the aim is to provide a primer and set the scene for discussing and evaluating whatever proposals the panel may put forward.

The next section briefly outlines the main issues at stake and discusses the current state of play. Section III reviews some of the major proposals for tax reform discussed over the past few years. Section IV discusses various international aspects of the reform proposals. Section $\mathrm{V}$ concludes.

\section{BACKGROUND AND ISSUES}

The Executive Order of January 7, 2005, requires the Advisory Panel on Tax Reform to submit to the Secretary of the Treasury revenue-neutral policy proposals which:

- $\quad$ "Simplify Federal tax laws to reduce the costs and administrative burdens of compliance with such laws;

- $\quad$ Share the burdens and benefits of the Federal tax structure in an appropriately progressive manner while recognizing the importance of homeownership and charity to the American Society; and

- $\quad$ Promote long-run economic growth and job creation, and better encourage work effort, saving and investment, so as to strengthen the competitiveness of the United States in the global marketplace.”

The Bush administration has, of course, already introduced significant tax changes, which are described in Box 1. These nevertheless have left a number of issues for continued discussion, including both fundamental structural issues - especially the long-standing debate on

\footnotetext{
${ }^{2}$ Nor does it deal with Social Security or the macro-fiscal challenges facing the United States.
} 
consumption versus income taxation and the case for adopting some form of value-added tax $(\mathrm{VAT})^{3}$-and more specific issues, such as the future of the alternative minimum tax, the marriage penalty, 401(k) plans, health insurance deductibility, and the deductibility of state and local taxes. There is, of course, an intimate link between the principles of tax reform and the specific instruments by which these principles are carried through. Before turning to various comprehensive reform proposals, the key issues in the debate are categorized below under the familiar concepts of efficiency, equity, and simplicity. ${ }^{4}$

\section{A. Efficiency}

\section{What to Tax: Income or Consumption?}

One of the main questions in the U.S. tax debate is whether the income tax should be replaced by a consumption tax. ${ }^{5}$ The main theoretical merit of such a shift is that the return to capital is not taxed under a pure consumption tax, hence there are no tax distortions to savings and investment decisions. On the other hand, the higher tax rate on labor income that is then needed to maintain revenue can be expected to worsen the distortion between work and leisure. This has led to an extensive theoretical literature characterizing the circumstances in which the optimal rate on capital income is zero. Chamley (1986), for instance, shows this to be the case in reasonably general circumstances so long as the government can commit to future tax rates. Ultimately, however, the importance of functional form and commitment issues is such that the literature reaches no entirely clearcut conclusion (see, for example, the recent review in Boadway and Keen, 2003).

Simulation exercises tend to suggest that a move towards a consumption tax would raise the overall level of income and perhaps even long-term economic growth. But there is considerable variation in the empirical estimates of how large such effects might be. Most studies find long-run increases in the level of output in the order of 10 percent (Altig and others, 2001; Edwards, 2005). Others find more significant effects, with real GDP levels increasing by 20-35 percent over the long term (Jorgensen and Yun, 2004). Importantly,

\footnotetext{
${ }^{3}$ U.S. Federal Reserve Chairman, Alan Greenspan, for example, has argued in favor of combining income and consumption taxation, although he appears to be opposed to the specifics of a VAT: like many other observers in the U.S. tax debate, he believes that the VAT is "an invisible tax" that too easily raises revenue (Tax Notes International, March 14, 2005). The IMF (2004b) has argued for the adoption of a federal VAT.

${ }^{4}$ Box 2 provides a quick guide to some of the key features of the current tax system that are under discussion.

${ }^{5}$ A consumption tax can be designed in many different ways, ranging from a single rate invoice-credit VAT to a progressive tax on ex post expenditure. Of particular relevance for the U.S. debate are the differences and similarities between ex post and ex ante taxation of consumption. Although they are conceptually different, they are identical in economic terms (Appendix I) with one important exception: the ex ante tax, such as a wage tax, simply excludes all capital income from taxation, whereas an ex post tax, such as an expenditure tax, by allowing a deduction for savings and by taxing withdrawals, effectively only excludes "normal returns" to capital from the tax net. Various ways of constructing a consumption tax are reviewed in section III.
} 
these simulations all assume that all exemptions, deductions, and credits are repealed instantly; that no transition relief is granted; and that the current progressive income tax rate structure is replaced by a single flat rate on consumption. Under more realistic assumptions - for example, keeping some kind of tax deduction for mortgage interest payments and charity, and/or allowing transition relief for those being hit by tax increasesthe output gains will diminish substantially or be entirely eliminated (Gale, 2004). Put differently, much of the gains from the various proposals for switching to a consumption tax come from broadening the tax base and lowering rates and might as well be reaped under an income tax.

The potential gains are also reduced once taking into account that the de facto change does not reflect a shift from a pure income tax system to a pure consumption tax system, but rather a shift from a system where most private savings already occurs in tax sheltered forms to a system where all private savings are tax free (Engen and Gale, 1996).

\section{Box 1. The Tax Cuts of 2001-2004}

The Bush administration implemented major tax packages in 2001 and 2003, both in the direction of lower marginal tax rates and lower taxation on savings (expanding tax-free savings accounts and reducing tax rates on dividends and capital gains). The administration also temporarily introduced a scheme that effectively allows expensing, rather than depreciating, a substantial part of new investment. Taken together, these measures could be viewed as an incremental approach to replacing the progressive income tax with a flat tax on consumption (Gale, 2004). However, the changes have only addressed one side of the coin. The other side—eliminating most, if not all, personal and corporate exemptions, deductions, and credits—has not been part of the tax packages. If these tax cuts are made permanent, as proposed by the administration in the past two budgets, there could be a permanent annual loss of revenue of around 2 percent of GDP by FY2014 (IMF, 2004a), although labor supply and other behavioral responses may dampen the revenue impact.

The 2001 and 2003 tax cuts featured the following key measures (most expiring by end FY2010): a reduction of federal individual income tax rates (for example, top rate reduced to 35 from 39.6 percent); a reduction of the estate tax (repealed in FY2010); a reduction (through FY2008) of the tax rates on dividends and capital gains to a top rate of 15 percent, from 39.6 and 20 percent, respectively; a reduction of the taxation of married couples (higher standard deduction, higher EITC, expanded brackets); a temporary (on a year-by-year basis) increase in the exemption level for the Alternative Minimum Tax (AMT); an increase in contribution limits to tax exempts saving accounts; and allowing deductions for educational expenses.

The Job Creation and Worker Assistance Act of 2002 allowed business to expense 30 percent of qualified capital equipment. This ratio was increased to 50 percent in 2003, but the partial expensing has now been repealed. The American Jobs Creation Act of 2004 repeals the ETI (exclusion from gross income for extraterritorial income for U.S. exporters), which was held to violate World Trade Organization (WTO) rules. The ETI is phased out until 2007 and is replaced by a new deduction for manufacturing and production activities. The act also includes various other tax reliefs as well as some base-broadening and anti-sheltering measures. 


\section{Box 2. U.S. Tax Expressions-A Mini-Glossary}

The U.S. tax debate is marked by its many acronyms. Here is a brief guide.

The Alternative Minimum Tax (AMT) is a separate tax schedule which exists for both individuals and corporations. The individual AMT has its own rates and (non-indexed) standard deduction and works as a backstop for the ordinary income tax system. Upper-income taxpayers must calculate an alternative version of taxable income and subject it to a two-rate scale, 26 and 28 percent (effective marginal rates could be higher due to exemption phase-outs). The final tax liability of each individual taxpayer is the greater of the AMT and the ordinary income tax liability. The corporate AMT also operates separately from the ordinary corporate income tax. It applies a tax rate of 20 percent to a broader definition of income, involving less generous depreciation and accounting rules. Firms pay the larger of the regular income tax and the AMT.

The earned income tax credit (EITC) is a tax credit provided for low-income wage earners and is phased out as income increases. The phase-out range depends on the number of dependents and marital status of the recipient. Unlike other tax credits, the EITC is refundable: if the EITC is larger than the tax liability, the recipient receives a check for the difference. The EITC was originally designed to offset social security payments for low-income families but has since been expanded to a program intending to improve work incentives for, and the well-being of the working poor.

The 401(k) and 403(b) plans are pension savings schemes, named after the section in the Internal Revenue Code that permits them. They are administered by employers, but the management of the investment decision is largely left to the individual employees. Likewise, self-employed can contribute to Keogh accounts. The individual retirement accounts (IRAs) are individual pension savings accounts. For all these schemes, contributions are tax deductible (within certain limits), as are earnings on savings as they accumulate. Withdrawals are not allowed before retirement age (without a penalty) and are taxed as income upon withdrawal. Roth IRAs, on the other hand, are taxed up front, but earnings on savings are accumulated free of tax.

The main argument against a shift to a consumption tax is the lower level of progressivity that such a shift would almost certainly imply (Gale, 2004). It would also imply that "old wealth” would be taxed twice: people with high current savings would already have paid income taxes, and would then be subject to a consumption tax as they spend their savings. Likewise, for businesses, “old capital” would not be fully depreciated, as immediate expensing of capital expenditure replaces the existing depreciation schemes used under the income tax. Hence, a shift to a consumption tax would impose a one-off tax on the owners of existing capital. Indeed, in several of these studies, much of the welfare gain from the shift to consumption taxation reflects the fact that it is in large part a capital levy on the elderly (Gale, 2004; Auerbach, Kotlikoff, and Skinner, 1983).

From an economic and generational point of view, this would not be a problem — perhaps even the contrary because older generations, the primary owners of existing capital, are also the generational "winners" under the current system (Kotlikoff, 2001). However, from a political perspective, such a tax would probably be perceived as unfair-especially by older people.

A transition relief could be enacted to alleviate these effects, but it would require higher tax rates to render the reform revenue neutral. This, in turn, would take away a substantial part of 
the efficiency-enhancing features of the reform: as mentioned, one of the main virtues, in economic terms, of a shift from an income tax to a consumption tax is exactly the one-off tax levied on existing wealth and capital.

One intermediate route from an income tax towards a consumption tax is to reduce and align tax rates on capital income (interest, dividends and capital gains), expand the range of taxfree savings(such as the 401(k)s and the IRAs) and allow for a partial expensing of investment-which is exactly the content of the Bush tax packages of 2001, 2002, and 2003 (Box 1). ${ }^{6}$ However, for such steps to be revenue neutral and symmetrical, and to avoid tax arbitrage, they should be accompanied by a reduction or elimination of interest deductibility (including mortgage deductibility) as well as other base-broadening measures. ${ }^{7}$

It is also doubtful whether the expansion of tax-free savings has contributed to an increase in national savings. A recent study by Bell, Carasso and Steuerle (2004) finds that tax expenditures on various pension savings schemes are now larger than total personal savings in the United States - one reason being that current tax incentives lead to a large extent to a reshuffling of existing wealth and savings that would take place anyway into tax-exempt vehicles. ${ }^{8}$ This indicates that current tax incentives may not be the best way to spur overall national savings, which is the sum of private and public savings. Gale (2005), for instance, argues that a more efficient way to achieve a net increase in private savings (and a more likely way to increase national savings as well) would be to reform the 401(k)s into a system under which a larger share of the workforce is automatically covered and the individual financial planning decisions for these schemes automated by “intelligent” defaults for escalation, portfolio balancing, and rollover. On a more general note, a more direct way to achieve larger national savings is to reduce the budget deficit (assuming that the private sector does not fully offset higher government savings).

\section{Should bequests and gifts be taxed?}

The estate tax is subject to a debate of its own. Opponents, who sometimes label it the "death tax," believe that the tax is unfair because it levies a double or triple tax on bequests and gifts (once when income is earned, then on return to savings, and finally when bequests or gifts are transferred from one generation to the next). However, some of the wealth subject to the estate tax may also reflect untaxed capital gains, which have never been subject to the income tax.

\footnotetext{
${ }^{6}$ See also the "five easy pieces" to a switch from income tax to consumption tax (Christian, 1998).

${ }^{7}$ Subsidies for housing are not confined to the deductibility of mortgage interest, but also include the deductibility of state and local property taxes and the (limited) exclusion of capital gains on primary residences.

${ }^{8}$ The debate over how much additional private savings is raised by the tax-exempt arrangements has raged for years without a final conclusion. Most studies seem to find that for each dollar put into an IRA or 401(k), about 25-40 cents are new savings; the rest is reshuffled from taxable savings (OECD, 2004a).
} 
In any case, it is a vital part of any system imposing a capital gains tax that death be treated as an event causing the realization of capital gains, otherwise the capital gains tax can be deferred through generations (implying major lock-in effects, as illustrated by the experience of for example, Japan-see Dalsgaard and Kawagoe, 1999). Moving the tax system in the direction of a consumption tax would strengthen the argument for keeping the estate tax, since most of the incomes of high-earning individuals may otherwise entirely escape taxation, thus rendering the consumption tax regressive rather than proportional to lifetime earnings. ${ }^{9}$

In this context, a pertinent observation is that most corporate income in the United States is not effectively taxed twice, due to corporate tax shelters and subsidies and the fact that more than half of dividends are untaxed or defer taxation at the individual level since they flow into pension funds, 401(k) plans, and nonprofits (Gale, 2002; Herd and Bronchi, 2001). In addition, the estate tax contains so many deductions and exemptions that less than 2 percent of estates actually face the tax (Burman, Gale, and Rohaly, 2005) and it only generates a yearly revenue of about 0.2 percent of GDP (1.3 percent of total federal revenue). The empirical evidence on saving behavior is ambiguous: the estate tax may discourage work and saving for people subject to it, but it has the opposite effect on their heirs who-expecting smaller bequests_-choose to work harder and save more (Burman, Gale, and Rohaly, 2005).

\section{Broadening the Tax Base}

Among the main sources of complexity and inefficiency of the income tax system is the widespread use of deductions, exemptions, and tax credits (Table 1). ${ }^{10}$ There has been a tendency to seek to accommodate a wide variety of policy objectives through the tax system, not least with respect to social and family policy. This has put the tax base, as well as the tax administration, under increasing pressure.

Together, these exemptions, deductions, and credits imply not only a substantial effective narrowing of the tax base, but also add to the complexity of the tax system and yield very

\footnotetext{
${ }^{9}$ The same effect could to a large extent be achieved by repealing the estate tax and extending the capital gains tax to define death and gifts as taxable events (with no allowance for step-up of the basis). However, potentially unwarranted side effects may arise related to small family-owned businesses and farms and the distribution of the tax gain (subjecting very large estates to the 15 percent capital gains tax rate rather than the 60 percent marginal estate tax rate). See Burman, Gale, and Rohaly (2005).

10 The cost of the exemptions and credits of the personal income tax system alone, in terms of revenue foregone, amounted to 6.2 percent of GDP in 2003 (IMF, 2004a)—or around 3/4 of the total revenue collected from individual income taxes. This number appears to be high compared with other OECD countries. Although no data are available to make direct cross-country comparisons, national studies from other OECD countries find tax expenditures in the personal income tax system to be in the order of 2-3 percent of GDP (Belgium, Holland), and tax expenditures for the entire system to be in the order of 4-5 percent of GDP (Australia, Denmark, Norway). See for example Brixi and others (2004) and OECD (2003).
} 
high effective marginal tax rates, even for moderate- to middle-income earners, as the deductions and credits are phased out (Steuerle, 2004).

Table 1. Selected Deductions, Exemptions, and Credits in the U.S. Personal Income Tax System ${ }^{1 /}$

\begin{tabular}{|c|c|c|}
\hline & Income Tax Expenditure, 2004 & $\begin{array}{l}\text { Billions of } \mathrm{L} \\
\text { (\% of GDP) }\end{array}$ \\
\hline \multirow[t]{6}{*}{ Deductions and exemptions } & Exclusion of pension contributions & $154\left(1 \frac{1}{2} \%\right)$ \\
\hline & $\begin{array}{l}\text { Exclusion of health insurance premiums and } \\
\text { medical care }\end{array}$ & $130(1 \%)$ \\
\hline & Deductibility of state and local taxes & $73(1 / 2 \%)$ \\
\hline & Deductibility of mortgage interest & $68(1 / 2 \%)$ \\
\hline & Charity & $43(1 / 3 \%)$ \\
\hline & Exclusion of interest on local and state bonds & $27(1 / 4 \%)$ \\
\hline \multirow[t]{4}{*}{ Tax credits } & Child tax credit & $21(1 / 4 \%)$ \\
\hline & Lifetime learning and HOPE tax credits & 6 (N/A) \\
\hline & Earned income tax credit & $5(\mathrm{~N} / \mathrm{A})$ \\
\hline & Child and dependent care tax credit & $3(\mathrm{~N} / \mathrm{A})$ \\
\hline
\end{tabular}

Source: United States Office of Budget and Management (2003), tables 6-3 and 6-4. See also Burman (2003).

1/ The numbers are on a cash basis and hence do not accurately capture the true economic cost of these provisions. The numbers also do not take into account revenue losses from other sources, such as the payroll tax. The refunded part of the earned income tax credit, some US\$ 33 billion in 2004, is shown as an outlay in the budget. Hence the total budgetary costs of the earned income tax credit amounted to some US\$ 38 million in 2004, about 1/3 percent of GDP.

However, some of these exemptions and credits are better founded in economic considerations than others: the charitable deduction, for instance, could be seen as an attempt to correct the "free rider" problem that could otherwise lead to an insufficient provision of charity. The health insurance deductibility may help to mitigate problems of adverse selection that could otherwise arise in a non-subsidized private health market (implying that those who would most likely be needing health services could be facing prohibitive insurance premiums) and hence contributes to extending health care to more people in the workforce. The earned income tax credit helps to reduce the disincentive of the "working poor" to take low-paying jobs (even though the effects of the EITC are theoretically ambiguous as income and substitution effects draw in opposite directions for lower incomes, and higher marginal tax rates discourage labor supply in the phase-out range). On the other hand, the deduction for local income and property taxes, or the exclusion of interest on state and local bonds, primarily acts as implicit subsidies to local and state governments (Rogers, 1999). 
In addition to the tax expenditures listed in Table 1, there are sizeable "hidden" tax expenditures, for example the non-taxation of some fringe benefits such as employer provided childcare, education benefits, and legal services (Rogers, 1999). Tax expenditures related to the non-taxation of imputed rental income of owner-occupied housing (which should in principle accompany mortgage interest deductibility in order not to unduly favor investment in housing) are not part of the standard budget presentation. However, they are implicitly included in Table 1 by way of the revenue foregone by mortgage interest deductibility, which could be considered a proxy for the tax expenditures related to the exclusion of imputed rental income (Burman, 2003).

Base broadening is also an issue in the taxation of corporations, where tax expenditures among other things are related to deferral of taxation of foreign-sourced income and accelerated depreciation. The notion of greater "book tax" conformity has received substantial attention in the tax debate- the idea being to close the gap between the profits that companies report to the public and the profits they report to Internal Revenue Service (IRS). ${ }^{11}$ This gap is caused by deductions, exclusions, and credits, which are valid for tax purposes only. ${ }^{12}$ However, closing corporate tax shelters may not be an easy political task, since every tax preference is there for a specific reason and is supported by often powerful vested interests.

There may also be valid economic reasons for not integrating book profits and tax profits, such as the need to provide capital markets with adequate information: if the financial and tax incomes were conformed in one single concept, it has been argued that this concept might end up closer to taxable income as defined under the current tax system, so that today's financial accounting measure of performance might no longer be available to markets (Hanlon and Shevlin, 2005). ${ }^{13}$ On the other hand, if taxable income were actually defined by the financial accounting income, as defined by the Financial Accounting Standards Board (FASB), the risk of base erosion through lobbyism and political pressure would probably be strongly reduced, as would the-increasing — part of tax sheltering that is explained by the use of incentive compensation (such as stock options) for corporate managers (Desai, 2002 and 2003).

\footnotetext{
${ }^{11}$ See for instance Joint Committee on Taxation, 2005. However, corporate tax expenditures, estimated at less than $1 / 2$ percent of GDP, are much lower than those related to individual income (IMF, 2004a). And there is evidence that the gap between book and tax income decreased around 2000-01 (Internal Revenue Service, 2005).

12 Manzon and Plesko (2002). Desai (2002) finds that the traditional explanations of book-tax discrepancies (such as stock options, deferral of income abroad, and depreciation differences) account for about half the gap, while the rest reflects unidentified opportunities in the tax code to manipulate income or outright evasion.

${ }^{13}$ Hanlon and Shevlin (2005) believe that merging the book and tax accounts would lead to a result closer to the tax account since Congress is unlikely to effectively leave the setting of important parameters in the corporate tax system to the private sector Financial Accounting Standards Board (FASB). Based on empirical observations, they also suggest that conforming the book and tax incomes is unlikely to lead to a reduction of the amount of sheltering by corporations.
} 


\section{B. Equity}

Considerations of horizontal equity - that taxpayers of equal income (or equal economic ability) should be treated equally-are highly prevalent, for instance in the debate on the so called marriage tax. In contrast to most other countries, the U.S. income tax system distinguishes between married and unmarried taxpayers. ${ }^{14}$ Horizontal equity issues arise because no tax system can accommodate the following three objectives at the same time: (i) a progressive rate structure; (ii) neutrality towards marriage; and (iii) tax liability independent of the distribution of income between married couples. ${ }^{15}$ To the extent that married couples are put at a disadvantage relative to two single individuals, the system imposes a "marriage penalty." This has been a long-standing issue in the U.S. tax debate (standard exemptions and income tax brackets, for instance, are not yet twice as high for married couples as for individuals), but the 2001 and 2003 tax changes addressed some of the main concerns. Indeed, even before these changes, evidence suggested that marriage bonuses are more prevalent than marriage penalties. ${ }^{16}$ Regardless, the marriage penalty remains an important part of the political agenda - but is not necessarily a first-order economic concern.

The issue of vertical equity - that taxpayers of higher income (or economic ability) should pay a relatively larger tax-has received renewed attention after the Bush tax cuts, which tend to favor higher-income households by eliminating the top personal rate and reducing taxation of capital income. The administration points to the fact that high-income households are now paying a larger share of the total income tax than before 2001. Others (Gale and Orszag, 2004) claim that this is a partial consideration, neglecting that the burden of financing the tax cuts will ultimately be borne by middle- and lower-income households. Other issues on the vertical equity agenda are the relative taxation of labor versus capital, as mentioned above, and the need to support poor households through tax credits. ${ }^{17}$

Many of the tax reform proposals discussed below specifically address the issue of vertical equity and the extent to which the tax system can be made simpler and no less progressive than today. This discussion, in turn, is complicated by the fact that consumption taxation need not be less progressive than income taxation, when measured over the life cycle of

\footnotetext{
${ }^{14}$ There are currently four tax filing categories: single filing; married couples filing jointly; married couples filing separately; and head of household.

${ }^{15}$ Hills (1988). See Appendix II for an illustrative example.

${ }^{16}$ A married couple with two children and income of an average production worker pays 60 percent of the taxes paid by a single taxpayer with no children and the same income, the most preferential ratio in the G7 (OECD, 2004b). The Congressional Budget Office (1997) found that in 1996, 42 percent of married couples were subject to a marriage penalty averaging 2.0 percent of their adjusted gross income, while 51 percent of married couples received marriage bonuses, averaging 2.3 percent of their adjust gross income.

${ }^{17}$ Indeed, the United States, to a much larger extent than most other OECD countries, pursues social policy objectives through the tax system (i.e., tax expenditures) rather than through the expenditure side of the budget.
} 
individuals. Effective life-time progression ultimately depends on the parameters (the tax rates, deductions, and credits) of the system, the mobility over time of individuals up and down the income scale, and the extent to which wealth can be transferred through generations.

Another aspect of this debate is the issue of intergenerational equity: the notion that future generations might be burdened more than current generations in terms of net tax payments (taxes minus transfers) over their life-times. Current fiscal policies in the United States, and many other OECD countries, imply a substantial problem of intergenerational inequity, with current generations benefiting at the cost of future generations. This inequity can be alleviated by policies that contribute to reducing government debt (here and now), and by individual decisions by current generations to spend less and leave more bequest to their heirs.

\section{Simplicity}

One of the most frequent complaints against the U.S. tax system is its complexity, with myriads of deductions, exemptions, and credits, and - not least - the alternative minimum tax (AMT). For the majority of individual taxpayers (those with wage income and simple capital income and deductions only), the compliance burden of the tax system is manageable, although not entirely trivial. ${ }^{18}$ For corporations and individuals with more complex incomes, the tax code is cumbersome, giving rise to high compliance costs both for the taxpayer and for the IRS. However, it is unclear whether the U.S. tax system as such is more complicated than in other OECD countries and whether compliance costs overall are larger, in particular since individual tax liabilities can be computed quickly and reliably by easy accessible computer programs, like TurboTax or TaxCut (which even enable the taxpayer to simulate the tax consequences of alternative decisions they may be considering). ${ }^{19}$

One of the major reasons for the complexity of the tax system is the AMT. The purpose of the AMT, which from 1969 replaced the existing minimum taxes, is to ensure that highincome individuals and corporations are less likely to escape the tax net entirely through tax avoidance ("creative" tax accounting), using the numerous exemptions and credits in the ordinary tax system. The AMT has had some success in increasing tax payments by high income households (IMF, 2004c), but at the cost of added complexity. Hence, individuals

\footnotetext{
${ }^{18}$ IRS estimates that, on average, it takes 3 hours and 43 minutes to prepare the simplest income tax form in the IRS inventory (1040EZ). Ironically, the complexity of the earned income tax credit and other tax reliefs for low-income households implies that these households often face much higher compliance costs than averageincome households.

${ }^{19}$ United States Treasury (2002) and Slemrod (1996) estimate total compliance cost of Federal income taxes to amount to around 10 percent of total revenue, or close to 1 percent of GDP. Hall (1995) and Payne (1993) find even higher compliance costs. Internationally comparable data are not available, but Slemrod (1996) mentions compliance costs of the income tax systems of the United Kingdom and Sweden to be about 5 and 3 percent of revenue, respectively.
} 
potentially subject to the AMT will have to calculate their tax liability under both the ordinary income tax scheme and the AMT to determine which system implies the largest tax liability, and then pay this larger liability. Moreover, as noted by Herd and Bronchi (2001), the individual AMT has not achieved its original goal of lowering the number of people who pay no tax.

The main problem of the individual AMT, however, is that it is projected to encompass an ever larger share of taxpayers, thanks in particular to the non-indexation of the standard deduction and brackets. Projections show that the number of individual taxpayers subject to the AMT will increase from 21/2 million in 2005 to around 30 million in 2010 (IMF, 2004c). This trend has been reinforced by the Bush tax cuts, which have reduced the ordinary tax burden of high-income households, and only temporarily (one year at a time in the annual budget) relieved them from increased AMT. ${ }^{20}$ The AMT hence (incidentally) automatically alleviates some of the budgetary pressure created by the 2001 tax cuts, and up to one third of the effects of these tax cuts will effectively be rolled back by increased AMT liabilities unless the AMT exemption continues to be raised (Burman, Gale, and Rohaly, 2003).

While not necessarily a first-order economic problem, the projected increase in the number of AMT filers could pose substantial political problems since a large share of the voters will eventually be subject to a higher income tax burden than today. It will also pose an additional compliance burden on these taxpayers, as well as on the IRS. The corporate AMT, while also imposing compliance costs on businesses, is not as controversial as the individual AMT and will not be further discussed here. ${ }^{21}$

\section{Proposals for TAX Reform}

Many proposals have been put forward for remedying the tax system, making it fairer, simpler, more transparent, and more conducive to savings and investment. Most of these proposals originate in the academic literature and, although experience suggests that they are unlikely to be adopted in pure form, they have contributed significantly to shaping the debate and bringing out key design issues. This section provides a brief overview of some of the most prominent proposals put forward over the past few years, ranging from incremental adjustment of the current system, to more radical shifts to a full-blown consumption tax. ${ }^{22}$

\footnotetext{
20 The AMT relief is not part of the 2005-06 budget proposal since the administration assumes that the AMT issue will be dealt with permanently in an upcoming tax reform.

${ }^{21}$ Many other countries also levy minimum taxes on corporations but, typically, in the form of some simple tax on assets (Mexico) or gross income (Philippines).

${ }^{22}$ A recent non-technical overview and discussion of some of these proposals can be found in Auerbach and Hassett (2005).
} 
Table 2. Key Elements of Six Reform Proposals (Revenue Neutral Under Current Law)

\begin{tabular}{l} 
Proposal \\
\hline \multicolumn{1}{c}{ 1. Treasury “option 5”: } \\
incremental adjustment \\
(United States Treasury, \\
2002)
\end{tabular}

2. Dual income tax (Edwards, 2005)

3. Combined VAT and income tax (Graetz, 2005; Avi-Yonah, 2005)

\begin{abstract}
4. Flat tax (Hall and Rabushka, 1985/1995)
\end{abstract}

5. Unlimited Savings

Accounts -- USA

(Seidman, 1997)

\section{Individuals:}

Repeal AMT; repeal deduction for state and local tax; increase standard deduction; repeal income-based phase-out of tax credits; expand tax-free savings accounts up to US\$10,000 per year per person.

Business:

Allow partial expensing for business investment; move 35 percent toward book-tax conformity by repealing special deductions, exclusions, and credits.

Individuals:

Repeal AMT and most exemptions and tax credits (keeping only deductibility for pension and health savings accounts and the EITC).

Business:

Exclude interest from tax base; repeal AMT.

Individuals:

Retain income tax base; repeal regular income tax and transform AMT into a single rate tax with indexed standard exemption of US\$100,000/50,000 for couples/singles; purge current itemized deductions, exclusions, and credits (not fully specified).

Business:

Approach book tax conformity; allow for integration with individual tax (no double taxation of dividends and capital gains); repeal corporate AMT.

VAT:

Introduce credit-invoice VAT (destination based).

\section{Individuals:}

Repeal all deductions and credits; exclude capital income from tax base; increase standard personal allowance.

Business:

Capital expensing; financial flows excluded from tax base; territorial system.

Individuals:

All savings deducted from income, all withdrawals taxed; large basic allowance; all other deductions and credits repealed.

Business:

Subtraction method VAT (capital expensing, nondeductibility of wages and salaries); introduce tax credit for payroll taxes.

6. National retail sales tax/ Replace all federal taxes by a uniform retail sales tax FairTax (Linder, 2005) on all goods and services (applying to final sales).

$10,15,25$, and

35 percent

Rates

Wage income: 15 and

27 percent

Capital income:

15 percent

Corporate income:

15 percent

Single rate: 25 percent

Single rate: 25 percent

Single rate: $10-15$

percent

Single rate: 19 percent

Single rate: 19 percent

Progressive rate: up to 40 percent

Single rate: 11 percent

Single rate: 23 percent Note: Appendix I provides a simplified overview of the economic similarities and differences between the proposals. Proposals 4, 5, and 6 would replace all current federal taxes (6 would also repeal payroll tax). 
The key features of the various tax reform proposals are summarized in Table 2, and their pros and cons are discussed below. ${ }^{23}$ Proposals 1,2 , and 3 are all framed within the current income tax system and could be implemented with relative practical (albeit not political) ease. Proposals 4, 5, and 6 would require more fundamental design changes, including in the taxation of the financial sector and cross-border flows of goods and services, since they all repeal the concept of an income tax (Shay and Summers, 1997). The proposals could in some instances be combined (for example, 2 and 3), and they could all be adjusted to include various features of the current system (for example, the EITC or other credits, exemptions, and deductions).

\section{A. Treasury “Option 5” (Incremental Adjustment)}

This is not a formal proposal of the administration. It originates from an internal Treasury Department memo, which was leaked in 2002. However, the memo has since been available from the internet and the content has been widely debated.

Pros: The proposal has the practical merit of keeping most elements of the current system, basically attempting to modestly simplify the system and broaden the bases for individual and corporate income taxes. The major achievement would be to get rid of the individual AMT, as well as the bulk of corporate tax shelters. The Treasury lists some optional add-ons to the proposal, which would allow lowering of rates: repeal deduction for charity and health insurance; tax most social security benefits; reduce child related and education credits.

Cons: It is not clear that the tax system overall would be less complex or the bases more broad, given for instance the expansion of the tax-free savings accounts and the partial expensing of business investment.

\section{B. Dual Income Tax}

This proposal is inspired by the "Nordic" model of taxing capital income at a low flat rate and labor income at a progressive scale, reflecting the relative sensitivity of tax bases to tax rates, in particular, by taking into account that financial capital is more internationally mobile than labor. Another rationale is that the deductibility of interest expenditures combined with high and/or progressive tax rates on nominal interest income can, and in some cases has, led to a net revenue loss from taxing capital income, especially in times of high inflation and high nominal interest rates - see for instance Gordon and Slemrod (1988) - and to considerable macroeconomic distortions in countries, such as Sweden and Denmark with overborrowing by private sector leading to twin trade and fiscal deficits in the 1970s and 1980s.

${ }^{23}$ Potential general equilibrium effects on prices, interest rates, or exchange rates are not considered. 
Pros: The dual income tax responds to these issues by applying a low flat rate on capital income and a progressive rate on wage income. ${ }^{24}$ The low tax rate on capital income would stimulate investment and possibly also savings (depending on income and substitution effects). The Edwards proposal also ends the distortion between new equity and debt by disallowing interest expenditure to be deducted from the business income base and by aligning the tax rates across financing and investment vehicles. ${ }^{25}$ Combined marginal tax rates (taking into account corporate income tax, individual income tax, and the federal payroll tax) would be lowered by 10-15 percentage points from current levels, making almost all sources of income taxed at marginal rates of 27-30 percent. Bases would be significantly broadened by eliminating most exemptions, deductions, and credits (bar the EITC) in the individual system, and for corporations the deductibility of state and local taxes and health insurance premiums. ${ }^{26}$

Cons: Less progressivity, in particular since taxation of capital income is reduced and most tax credits eliminated; the reduced taxation of capital income compared with labor income may give rise to fairness concerns; doubtful whether base broadening is politically viable (see Flat Tax below). To finance the reduction of the corporate rate to 15 percent, corporate subsidies on the spending side will have to be cut (by an amount not specified in the proposal).

\section{Combined VAT and Income Tax}

This is the only proposal among the six that combines an income tax with a federal consumption tax. As such, it brings the structure of the U.S. tax system closer to those of other OECD countries.

Pros: The personal allowance would be raised to such a level that an estimated 100-150 million taxpayers would no longer need to file an income tax return, and the rest would be

\footnotetext{
${ }^{24}$ The tax systems of the four Nordic Countries — Denmark, Norway, Sweden, and Finland — all include substantial elements of a dual income tax, although the individual solutions differ somewhat (Soerensen, 1998; Zee, 2005). For instance, Finland and Norway — but not Denmark and Sweden — apply integration of the personal and corporate income tax (thereby avoiding double taxation of dividends), while Norway is the only country to apply a variant of the capital gains tax, where only capital gains beyond those arising from retained earnings are taxed. The most difficult issues arising from the differentiation between labor and capital income are related to the taxation of the self-employed.

${ }^{25}$ In contrast to corporate integration, which eliminates double taxation of both interest and dividends, the proposal to disallow interest deductibility puts interest and dividend income on an equal footing by applying double taxation of both types of income (normally, only dividends are subject to double taxation).

${ }^{26}$ The corporate part of the dual income tax could be moved all the way into a Hall-Rabushka cash-flow business tax with four further steps: (i) replace depreciation with capital expensing; (ii) replace accrual accounting by cash accounting; (iii) replace worldwide taxation by territorial taxation; and (iv) extend the tax from corporations to all businesses (Edwards, 2005).
} 
subject to a low flat rate. The loss of revenue would be offset by a new federal VAT. Corporate tax shelters would be reduced, and the integration of corporate and individual taxes would reduce distortions to savings and investment, both by lowering marginal tax rates and by aligning the taxation of debt and new equity (but could be difficult to implement in practice, not least with respect to multinationals). Overall, the proposal would result in significantly lower taxation of capital income, lower marginal rates, and broader bases. The income tax system would be greatly simplified, and the VAT would be the orthodox invoicecredit type applied in most other countries.

Cons: As an intermediate step towards a consumption tax, this proposal would raise issues of transition (taxing existing wealth twice). To the extent state and local income taxes are not changed, some of the simplification gains are lost. The proposal to integrate corporate and personal income tax also appears to go against a global—or at least European-trend towards a "classical system," with dividends taxed at personal level and no relief for corporate taxation. $^{27}$ The most important "showstopper," however, could be the inability to muster political backing for a federal sales tax, given the long-established dominance of states in the domain of sales taxation. Keen (2001) proposes a solution that allows individual states to retain full discretion over the tax rates on final sales and taxes interstate transactions between registered traders at a single, positive rate. The proposal — the so-called VIVAT-hence addresses the problem of applying zero-rating to interstate sales (in the absence of border controls), but not the problems associated with out-of-state sales, including internet sales, to final consumers (which already arise under the current state retail sales taxes). A final consideration may be the administrative challenges this proposal would pose for the IRS in terms of administering the VAT, a tax which has features that are fundamentally different from existing U.S. taxes (however, other countries have managed to successfully implement the VAT quite quickly, as detailed in Ebrill and others, 2001).

\section{Flat Tax}

The flat tax proposal was first publicized in a Hall-Rabushka article in the Wall Street Journal's editorial page on December 10, 1981. This was followed up by Hall and Rabushka (1985) and later introduced in Congress by the Armey-Shelby tax proposal (H.R. 1040 of 1997).

Pros: The flat tax combines a single rate tax on individual wages, salaries, and pension income with a cash-flow tax for businesses, where deductions are allowed not only for purchases from other businesses, but also for cash wage and salary payments and employer pension contributions. The proposal has the merit of radically changing the tax system in the

\footnotetext{
${ }^{27}$ The non-discrimination provisions of the EU Treaty, as for instance applied in the EU Parent/Subsidiary Directive, deter many countries from applying an integrated system, but other concerns (including complexity in relation to cross border flows) have also played a role in moving countries like the United Kingdom, Germany and Italy away from corporate integration.
} 
direction of greater efficiency and simplicity. ${ }^{28}$ By shifting to a cash-flow, consumption tax base, incentives to save and invest are no longer distorted by taxation. The flat tax implies that normal returns to capital are untaxed, while extraordinary returns (rents) at the business level are taxed at the flat rate. In contrast, rents are not taxed at the individual level since all capital income is exempt. ${ }^{29}$ The broadening of the base result in a lower marginal tax rate on labor income. The flat tax also equalizes marginal tax rates across different industries, assets, and investments, hence eliminating current distortions to financing and savings decisions. ${ }^{30}$

Cons: The shift to a consumption tax will, as mentioned above, imply that existing capital would be taxed twice and that homeowners would likely suffer a capital loss on their principal residence since the mortgage deduction would be repealed. ${ }^{31}$ Also, contributions to charity and health insurance coverage would be reduced. Transition rules could alleviate this problem but would also imply a higher tax rate, lowering the efficiency gain. The flat tax is unlikely to be able to achieve the level of progressivity embedded in the current income tax system, in particular by disallowing progressive tax rates to be applied to labor income, but also by excluding taxation of interest, dividends, and capital gains at the individual level. ${ }^{32}$ The business tax is much like an origin-based subtraction type VAT (except that wages are also deductible here), which is normally considered to be less easy to administer than the standard invoice-credit VAT (the reason being that many features of the income tax administration would still have to be in place to police deductions-see Avi-Yonah, 2005).

\section{E. Unlimited Savings Accounts (USA)}

This proposal is in many respects akin to the flat tax proposal and hence is subject to the same pros and cons. ${ }^{33}$ Major differences are:

\footnotetext{
${ }^{28}$ The original Hall-Rabushka proposal claimed that all taxpayers would be able to file on a postcard-sized return. This proposition has since been widely disputed.

${ }^{29}$ A variant of the flat tax proposal includes financial flows (net increase in debt and capital income taxable) in the tax base.

${ }^{30}$ These distortions, however, have in any event tended to decline since the 1980s, when the proposal was first floated, due to lower marginal tax rates and lower inflation.

${ }^{31}$ These effects are more controversial, however, since the flat tax could potentially lead to a fall in the (gross) interest rates as interest expenditures are no longer deductible and interest income no longer taxed (Hall and Rabushka, 1985), thereby offsetting the effects of the elimination of the mortgage deduction.

${ }^{32}$ Bradford (1986) propose an amendment to the flat tax, the so-called X-tax, under which wages and salaries could be taxed at progressive rates, and some of the transitional issues are addressed. Progressivity also could be imposed by applying an EITC, although this would imply that the tax rate(s) would be higher.

${ }^{33}$ See also Appendix I.
} 
- $\quad$ Individual income (after deduction of savings) is taxed under a progressive rate scale;

- $\quad$ Rents are taxed both at the individual and business level (while only at the business level under the flat tax);

- $\quad$ The USA disallows wage deductibility for business, implying that wage income is taxed twice (although the effect of this, at least in part, is offset by the proposed new tax credit at the business level for payroll taxes);

- $\quad$ The USA lends itself less easily to wage withholding than the flat tax since the tax liability is not known until information on net savings is available by the end of the year;

- $\quad$ The USA would possibly impose additional administrative difficulties, confining the relevant set of registered assets and tracking the savings and dissavings of each audited taxpayer (in financial institutions and elsewhere, at home and abroad); this may also raise issues about taxpayer privacy (Edwards, 2005)

\section{F. National Retail Sales Tax}

This is the only proposal among the six that solely relies on a transaction-based consumption tax. The leading proposal for a federal retail sales tax is the so-called FairTax.

Pros: Replacing incomes taxes by a consumption tax would be expected to yield efficiency gains, depending on the specific design, as discussed above. The federal RST is designed to address the major flaws of the current state RSTs, which generally: do not apply to services; apply to business-to-business transactions (implying cascading of taxes); do not apply to catalog and e-commerce sales.

Cons: The federal RST will be more regressive than the income tax it replaces, since a transaction tax cannot take into account the personal characteristics of the buyer. ${ }^{34} \mathrm{~A}$ relatively high rate is likely to be required for revenue neutrality, which makes the tax vulnerable to evasion - much more so than a VAT at the same rate (since, under the latter, the government receives revenue from each step in the value chain). ${ }^{35}$ There is also a risk of

\footnotetext{
${ }^{34}$ It would, in principle, be possible to compensate poor households by way of sending a check each month, for example, to offset the burden of the tax up to the poverty line (as suggested in the FairTax proposal).

${ }^{35}$ Gale (2004) argues that the FairTax proposal suggesting a 23 percent tax inclusive rate is flawed (for instance, it applies different assumptions to the effects on producer prices on the revenue and expenditure sides of the budget), and that even under very conservative assumptions on evasion, avoidance, and statutory base erosion, a rate of 38 percent (tax inclusive) would be necessary to replace all federal taxes. This would come on top of the state and local sales taxes, which have combined rates of up to 11 percent (Edwards, 2005). Retail sales taxes at such high rates have not been implemented in other countries (where rates are typically below 10 percent). See Gale (2004) and Tanzi (1995).
} 
the RST being diluted over time by demands and pressures for exemptions-such as for child care, rent, food, health care-and for the introduction of multiple rates. On the administrative side, there may be serious negative repercussions on compliance with state income taxes, since these are based on the same income concepts and data currently applied and administered by the IRS. If IRS were to discontinue its income tax operations, states could find it difficult to continue to apply income taxes (which account for substantial revenues in many states). Finally, if administration of the RST is left up to the states, as suggested by several proponents of the federal RST, these may not have strong incentives to enforce the tax with sufficient rigor (on the contrary, some sort of "tax competition" may evolve leading to more lax administration over time).

In conclusion, the three radical reform proposals (4, 5, and 6) would probably achieve most in terms of improving efficiency and simplicity compared with the current system. But the three more moderate reform proposals (1, 2, and 3) are probably more politically viable in terms of having less pronounced distributional effects as well, perhaps, as readier applicability (for example, with respect to international aspects — see below-and the coherence vis-à-vis existing state and local tax systems).

\section{INTERNATIONAL ASPECtS}

\section{A. Foreign Direct Investment and Tax Treaties}

Reforms that replace the income tax with a consumption tax (i.e., proposals 4, 5, and 6) may have substantial international ramifications, but the effects are not clear-cut. Avi-Yonah (2005) argues that: "a situation in which the U.S. does not levy taxes on the normal return on capital, while the rest of the world has a normal corporate income tax, is untenable. It would result in massive shifts of capital to the U.S., the unraveling of the income tax treaty network, and either the end of the income tax in other countries, or a 'tax war' in which those countries try to capture the revenue we have foregone to tax." On the other hand, Shay and Summers (1997) hold that: "Even with substantially reduced U.S. tax rates, an incentive may remain in certain cases to locate investment outside the U.S. in order to take advantage of the territorial nature of the consumption tax base.”

The reason why the entire U.S. tax treaty network might have to be modified is that it is unclear whether the flat tax or the USA would qualify as income taxes in other countries, potentially blocking foreign tax credits for taxes paid in the United States (Avi-Yonah, 2005). ${ }^{36}$

From the perspective of developing countries, the abolition of U.S. world-wide taxation may seem preferable to the current situation since the tax relief for foreign investors frequently

\footnotetext{
${ }^{36}$ This only concerns the taxation of rents, since normal returns would be tax free anyway (Avi-Yonah, 2005). However, other countries may take advantage of the zero-income taxation in the United States to step up taxation of returns earned in the United States.
} 
provided in these countries will then benefit the investor rather than the U.S. Treasury. However, the other side of the coin is that developing countries would no longer have the option to take advantage of the U.S. foreign tax credit to soak up revenue by setting their own corporate tax rates up to the level of the U.S. corporate tax rate without effectively taxing U.S. multinationals (since these get a credit for the tax paid abroad). ${ }^{37}$

Developing countries also may be more concerned that the favorable taxation of investment in the United States under the reform proposals may trigger another round of unwanted tax competition to attract foreign investment (Shay and Summers, 1997).

Another international aspect of U.S. tax reform is the role of exchange of information. Under the current system of worldwide taxation, the United States has a vested interest in being able to obtain information from other countries on income earned by U.S. individuals and corporations. This is one of the main purposes of the net of tax treaties that the United States maintains with foreign counterparts. In the event the United States moves towards a territorial system, this incentive would disappear, and other countries might also follow suit. This, in turn, could harm efforts, by the OECD for example, to curb harmful tax competition. $^{38}$

\section{B. Compliance with WTO}

The Flat Tax would not qualify as an indirect tax under current WTO rules because wages are deductible (in contrast to a subtraction-type VAT). Hence, no rebate for taxes on exports would be allowed. ${ }^{39}$

The USA tax proposal features the characteristics for qualifying as an indirect tax for WTO purposes, although the tax credit for payroll taxes embedded in the proposal may be interpreted as a prohibited exemption of direct taxes (Shay and Summers, 1997).

\footnotetext{
${ }^{37}$ Nonetheless, empirical evidence suggests that U.S. multinationals do take corporate tax rates abroad into consideration when deciding on investment locations overseas, due, for example, to the possibility of deferring repatriation of income (Hines, 2001; Gordon and Hines, 2002).

38 That being said, the United States tends to rely more on bilateral agreements on information exchange than on multilateral frameworks, such as those promoted by the OECD.

${ }^{39}$ In theoretical terms, this would normally not be considered a problem since exchange rates or domestic relative prices move to offset differences in taxation. However, exchange rates may take a long while to adjust, the adjustment may not be tailored to the sectoral composition of the tax-disadvantage, and the adjustment may be less visible and blurred by other factors affecting the exchange rate. It is noteworthy that the executive order for the advisory panel specifically mentions the "competitiveness of the United States in global markets"which seems to suggest that border adjustability may be an important issue.
} 


\section{ConClusion}

The debate on tax reform in the United States is striking both in the innovativeness of the proposals it has generated and, to some observers, in the broad omission from discussion of the potential for improving the overall efficiency of the tax system by, for instance, raising energy taxes. ${ }^{40}$

The debate is notable too for the existence of widespread agreement that the current system is too complex and distortionary and needs to be improved, combined with wide disagreement — beyond the need to revamp the individual AMT_-on exactly how best to make the system simpler, more fair, and less distortionary to savings and investment. Few would disagree that the panel has a difficult task.

\footnotetext{
${ }^{40}$ Energy taxes in the United States are very low by international standards. Prust and Simard (2004) estimate that raising gasoline taxes by a moderate 20 cents per gallon could yield revenue of around $1 / 4$ to $1 / 2$ percent of GDP. Moving toward levels of energy taxation that would be sufficient to cover some of the external social costs (related to pollution, congestion, and accidents caused by driving) would require much more substantial hikes in the rates of gasoline taxes and other energy taxes. Parry and Small (2002), for instance, find that an increase of about 60 cents per gallon of gasoline (from currently around 40 cents to around \$1) could be justified on these grounds.
} 


\section{References}

Aaron, Henry J., 1997, “Death and Taxes: Now’s Hardly the Time to Favor the Richest Among Us," The Washington Post, May 4.

Altig, David, Alan J. Auerbach, Laurence J. Kotlikoff, Kent A. Smetters, and Jan Walliser, 2001, "Simulating Fundamental Tax Reform in the United States,” American Economic Review, Vol. 91, No. 3, pp 574-595.

Auerbach, Alan J. and Kevin A. Hassett (eds.), 2005, Toward Fundamental Tax Reform, The AEI Press, Washington, D.C.

Auerbach, Alan J., Laurence J. Kotlikoff, and Jonathan Skinner, 1983, “The Efficiency Gains from Dynamic Tax Reform,” International Economic Review, Vol. 24(1), pp 81-100.

Avi-Yonah, Reuven S., 2005, "Risk, Rents, and Regressivity; Why the United States Needs Both an Income Tax and a VAT,” Tax Notes International, January.

Bartels, Larry M., 2004, "Homer Gets a Tax Cut: Inequality and Public Policy in the American Mind,” Paper presented at the 2003 Annual Meeting of the American Political Science Association.

Bell, Elizabeth, Adam Carasso, and C. Eugene Steuerle, 2004, "Retiring Saving Incentives and Personal Saving,” Tax Notes, December 20.

Brixi, Hana Polackova, Christian M.A. Valenduc, and Zhicheng Li Swift (eds.), 2004, Tax Expenditures-Shedding Light on Government Spending through the Tax System, Washington: The World Bank.

Bradford, David F., 1986, Untangling the Income Tax, Cambridge, Massachusetts: Harvard University Press.

Boadway, Robin, and Michael Keen, 2003, “Theoretical Aspect on the Taxation of Capital Income and Financial Services,” in Taxation of Financial Intermediation: Theory and Practice for Emerging Economies, ed. by Patrick Honohan, Washington: World Bank.

Burman, Leonard E., 2005, “The Individual Alternative Minimum Tax,” Presentation for the Presidents Advisory Panel on Federal Tax Reform, March 3. , 2003, “Is the Tax Expenditure Concept Still Relevant?” National Tax Journal, September.

Burman, L., William G. Gale, and J. Rohaly, 2005, “Options to Reform the Estate Tax,” Tax Policy Issues and Options No. 10, Urban-Brookings Tax Policy Center. 
Burman, L., William G. Gale, and J. Rohaly, 2003, “The AMT: Projections and Problems,” Tax Notes, July 7.

Chamley, Christophe, 1986, “Optimal Taxation of Capital Income in Generational Equilibrium with Infinite Lives,” Econometrica, 54 (3).

Christian, Ernest, 1998, “De-Radicalizing Tax Reform,” Tax Notes, April 13.

Congressional Budget Office, 1997, For Better or for Worse: Marriage and the Federal Income Tax, CBO Study, Washington: U.S. Government Printing Office.

Dalsgaard, Thomas, and Masaaki Kawagoe, 1999, “The Tax System in Japan: A Need for Comprehensive Reform”, OECD Economic Department Working Papers No. 231.

Desai, Mihir A., 2003, “Corporate Tax Avoidance and High Powered Incentives,” unpublished. , 2002, "The Corporate Profit Base, Tax Sheltering Activity, and the Changing Nature of Employee Compensation,” NBER Working Paper No. 8866.

Ebrill, Liam, Michael Keen, Jean-Paul Bodin, and Victoria Summers, 2001, The Modern VAT, International Monetary Fund, Washington, D.C.

Edwards, Chris, 2005, “Options for tax Reform,” Policy Analysis No. 536, Washington: Cato Institute.

Engen, Eric M., and William G. Gale, 1996, “The Effects of Fundamental Tax Reform on Saving, in Economic Effects of Fundamental Tax Reform, ed. by Henry J. Aaron and William Gale, Washington: Brookings Institution Press.

Gale, William G., 2005, “The Automatic 401(k): A Simple Way to Strengthen Retirement Savings,” The Brookings Institution, Retirement Security Project No 2005-1, March. , 2004, "Federal Revenue Options," Testimony Submitted to the United States House of Representatives, Committee on the Budget.

, 2002, “About Half of Dividend Payments Do Not Face Double Taxation,” Brookings Institution Tax Notes, November 11. , and Peter R. Orszag, 2004, “Bush Administration Tax Policy: Distributional Effects,” Brookings Institution Tax Notes, September 27.

, 2000, “Resurrecting the Estate Tax,” The Brookings Institution Policy Brief No. 62, June. 
Gordon, Roger H., and James R. Hines Jr, 2002, “International Taxation,” in Handbook of Public Economics, Vol. 4, ed. by Alan J. Auerbach and Martin Feldstein, Amsterdam: North-Holland.

and Joel Slemrod, 1988, “Do We Collect Any Revenue from Taxing Capital Income?” in Tax Policy and the Economy, ed. by Lawrence H. Summers, Cambridge, Massachusetts: The MIT Press.

Graetz, Michael J., 2005, “A Fair and Balanced Tax System for the 21th Century”, The Public Interest, February 2005.

Gravelle, Jane G., 2003, “The Enron Debacle: Lessons for Tax Policy,” Tax Policy Center Discussion Papers No. 6, February.

Hall, Arthur, 1995, “Compliance Costs of Alternative Tax Systems,” Testimony to the House Ways and Means Committee, June 6.

Hall, Robert E., and Alvin Rabushka, 1985 and 1995 (2. edition), The Flat Tax, Hoover Institution Press, Stanford, California.

Hanlon, Michelle and Terri Shevlin, 2005, "Book-Tax Conformity for Corporate Income: An Introduction to the Issues”, Tax Policy and the Economy No. 18, ed. by James M. Poterba, National Bureau of Economic Research, Cambridge, MA.

Herd, Richard and Chiara Bronchi, 2001, "Increasing Efficiency and Reducing Complexity in the Tax System in the United States”, OECD Economic Department Working Papers No. 313, Paris: Organization for Economic Coorperation and Development.

Hills, John, 1988, Changing Tax, CPAG Limited, London.

Hines, James R. Jr, 2001, “Tax Sparing and Direct Investment in Developing Countries,” in International Taxation and Multinational Activity, Chicago: Chicago University Press.

IMF, 2004a, “United States: Perspectives on Fiscal Consolidation”, Selected Issues Paper for the Article IV Staff Report, International Monetary Fund, Washington, D.C.

, 2004b, United States: 2004 Article IV Consultation - Staff Report, International Monetary Fund, Washington, D.C.

, 2004c, “The Increasing Scope of the Alternative Minimum Tax,” Selected Issues Paper for the Article IV Staff Report, International Monetary Fund, Washington, D.C.

Internal Revenue Service, 2005, “Reconciling Corporation Book and Net Tax Income,” Tax Years 1995-2001, Statistics of Income Winter 2004-2005 Bulletin, pp. 103-108. 
Joint Committee on Taxation, 2005, Options to Improve Tax Compliance and Reform Tax Expenditures, JCS-02-05, Washington, DC: U.S. Government Printing Office.

Jorgenson, Dale, and Kun-Young Yun, 2001, Lifting the Burden: Tax reform, the Cost of Capital, and US Economic Growth, Cambridge, Massachusetts: The MIT Press.

Keen, Michael, 2001, “States’ Rights and the Value Added Tax: How a VIVAT Would Work in the United States,” National Tax Association Proceedings, Vol 94, Annual Conference on Taxation.

Kotlikoff, Laurence J., 2001, “Generational Policy,” NBER Working Paper no. 8163, National Bureau of Economic Research (also appearing in the second edition of The Handbook of Public Economics).

Linder, John, 2005, “FairTax Act of 2005”, H.R. 25 (as introduced in the House of Representatives).

Manzon, Gil B. and George Plesko, 2002, “The Relation Between Financial and Tax Reporting Measures of Income,” Tax Law Review 55, Winter.

OECD, 2004a, “Tax Favored Retirement Savings Plans: A Review of Budgetary Implications and Policy Issues,” Working Party No. 1 on Macroeconomic and Structural Policy Analysis, Paris: Organization for Economic Coorperation and Development.

OECD, 2004b, Taxing Wages, Paris: Organization for Economic Coorperation and Development. , 2003, Economic Outlook, December. Paris: Organization for Economic Coorperation and Development.

Parry, Ian W.H and Kenneth A. Small (2002), "Does Britain or the United States have the Right Gasoline Tax”, RFF Discussion Paper, 02-12-2002, Washington: Resources for the Future.

Payne, James L., 1993, Costly Returns: The Burdens of the US Tax System, San Francisco: ICS Press.

Prust, J., and D. Simard, 2004, “U.S. Energy Policy: Role of Taxation,” in U.S. Fiscal Policies and Priorities for Long-Run Sustainability, ed. by M. Muhleisen and C. Towe, IMF Occasional Paper No. 227, Washington: International Monetary Fund.

Rogers, Diane Lim, 1999, “Federal Income Tax Policy,” in Handbook on Tax Policy, ed. by W. Bartley Hildreth and James A. Richardson, New York: Marcel Dekker Inc. 
Seidman, Laurence S, 1997, The USA Tax: A Progressive Consumption Tax, Cambridge: MIT Press.

Shay, Stephen E. and Victoria P. Summers, 1997, "Selected International Aspects of Fundamental Tax Reform Proposals”, University of Miami Law Review, Vol. 51, No. 4.

Slemrod, Joel, 1996, “Which Is the Simplest Tax System of Them All?” in Economic Effects of Fundamental Tax Reform, ed. by Henry J. Aaron and William Gale, Washington: Brookings Institution Press.

Soerensen, Peter B., 1998, "Recent Innovations in Nordic Tax Policy: From the Global Income Tax to the Dual Income Tax,” in Tax Policy in the Nordic Countries, ed. by Peter B. Soerensen, London: Macmillan Press.

Steuerle, Eugene C., 2004, “Tax reform: Prospects and Possibilities,” Statement Before the Committee on the Budget, United States House of Representatives.

Tanzi, Vito, 1995, Taxation in an Integrating World, Washington: Brookings Institution Press.

United States Office of Budget and Management, 2003, Analytical Perspectives, Budget of the United States Government, Fiscal Year 2004, Washington: U.S. Government Printing Office.

United States Treasury, 2002, “Memorandum for Secretary O’Neill,” unpublished.

Zee, Howell H., 2005, "Personal Income Tax Reform: Concepts, Issues, and Comparative Country Developments,” IMF Working Paper 05/87, Washington: International Monetary Fund. 


\section{Appendix I. Economic Similarities and Differences Among Tax Reform Proposals ${ }^{41}$}

Consider the following national accounts identities (closed economy case):

(1) $\mathrm{Y}=\mathrm{C}+\mathrm{I}$ (gross national income $=$ consumption + interest $)$

(2) $\mathrm{Y}=\mathrm{W}+\mathrm{R}+\mathrm{P}+\mathrm{D}$ (gross national income $=$ wages + interest + profits + depreciation $)$

(3) $\mathrm{I}=\mathrm{S}$ (investment $=$ savings)

Based on these simple accounting relations, the differences and similarities of various proposals for US tax reform are illustrated in the table below.

\begin{tabular}{|c|c|c|c|}
\hline Reform proposal & $\begin{array}{l}\text { Personal income tax } \\
\text { liability } 1\end{array}$ & $\begin{array}{l}\text { Corporate income tax } \\
\text { liability }\end{array}$ & Tax rates \\
\hline $\begin{array}{l}\text { Current income tax } \\
\text { (double taxation of } \mathrm{P} \text { ) }\end{array}$ & ${ } \mathrm{P}(\mathrm{W}+\mathrm{R}+\mathrm{P})$ & $\tau^{\mathrm{C}}(\mathrm{P})$ & $\begin{array}{l}\tau \mathrm{P}(\text { high })>\tau \mathrm{P}(\text { low }) \\
\tau^{\mathrm{C}}(\text { high })>\tau^{\mathrm{C}}(\text { low })\end{array}$ \\
\hline Dual income tax & ${ }_{\tau} \mathrm{Pl}_{(}(\mathrm{W})+\tau \mathrm{Pc}_{(\mathrm{R}+\mathrm{P})}$ & $\tau^{\mathrm{C}}(\mathrm{P})$ & $\tau^{\mathrm{Pl}}>\tau{ }^{\mathrm{PC}}=\tau^{\mathrm{C}}$ \\
\hline Wage tax & $\begin{array}{l}{ }^{\mathrm{p}} \mathrm{PW}(\mathrm{W}) \\
\text { (ex ante consump. tax) }\end{array}$ & - & $\begin{array}{l}\text { X-tax: } \\
{ }_{\tau} \mathrm{pW}_{(\text {high })>\tau} \mathrm{pW}_{(\text {low })}\end{array}$ \\
\hline Expenditure tax & $\begin{array}{l}{ }{ }^{\mathrm{PE}}(\mathrm{Y}-\mathrm{S})= \\
{ } \mathrm{pW}_{(\mathrm{W})} \\
\text { (ex post consump. tax) }\end{array}$ & - & ${ }_{\tau} \mathrm{pE}_{>\tau} \mathrm{pW}$ \\
\hline Flat tax & ${ } \mathrm{pW}_{(\mathrm{W})}$ & $\begin{array}{l}\tau^{\mathrm{C}}(\mathrm{P}+\mathrm{R}+\mathrm{D}-\mathrm{I})= \\
\tau^{\mathrm{C}}(\mathrm{Y}-\mathrm{W}-\mathrm{I}) \\
\text { (= cash flow tax for } \\
\text { business) }\end{array}$ & $\tau \mathrm{P}=\tau^{\mathrm{C}}=\tau$ \\
\hline $\begin{array}{l}\text { Unlimited Savings } \\
\text { Accounts } \\
\text { (double taxation of W) }\end{array}$ & ${ }^{\mathrm{pE}}(\mathrm{Y}-\mathrm{S})$ & $\begin{array}{l}\tau^{\mathrm{C}}(\mathrm{Y}-\mathrm{I}) \\
\text { (= subtraction VAT for } \\
\text { business) }\end{array}$ & $\begin{array}{l}{ } \mathrm{pE}_{(\text {high })>\tau} \mathrm{pE}_{(\text {low })} \\
\tau^{\mathrm{c}}=\tau\end{array}$ \\
\hline
\end{tabular}

${ }^{41}$ This appendix is inspired by Zee (2005). 


\section{Appendix II. The Marriage Penalty-An Example}

Consider 4 couples: 1, 2, 3 and 4. Couples 1 and 2 are singles, while 3 and 4 are married. The tax system applies two brackets with rates of 10 and 40 percent, respectively. Depending on whether the brackets are identical for singles and married couples, there are penalties or benefits of getting married (Table 3).

Case I) is where tax brackets are the same:

Singles and married couples:

Income up to 50,000 is taxed at $10 \%$

Income above 50,000 is taxed at $40 \%$

Case II) is where brackets are twice as large for married couples:

Singles:

Income up to 50,000 is taxed at $10 \%$

Income above 50,000 is taxed at $40 \%$

Married couples:

Income up to 100,000 is taxed at $10 \%$

Income above 100,000 is taxed at $40 \%$

Table 3. Total Tax Payments

\begin{tabular}{|c|c|c|c|c|c|c|c|c|}
\hline \multirow[b]{2}{*}{ Income } & \multicolumn{2}{|c|}{ Couple 1: Singles } & \multicolumn{2}{|c|}{ Couple 2: Singles } & \multicolumn{2}{|c|}{ Couple 3: Married } & \multicolumn{2}{|c|}{ Couple 4: Married } \\
\hline & $\begin{array}{l}\text { Earner A: } \\
100,000\end{array}$ & $\begin{array}{l}\text { Earner B: } \\
0\end{array}$ & $\begin{array}{l}\text { Earner A: } \\
50,000\end{array}$ & $\begin{array}{l}\text { Earner B: } \\
50,000\end{array}$ & $\begin{array}{l}\text { Earner A: } \\
100,000\end{array}$ & $\begin{array}{l}\text { Earner B: } \\
0\end{array}$ & $\begin{array}{l}\text { Earner A: } \\
50,000\end{array}$ & $\begin{array}{l}\text { Earner B: } \\
50,000\end{array}$ \\
\hline $\begin{array}{l}\text { I. Same } \\
\text { brackets }\end{array}$ & & & & & & & & \\
\hline Individual tax & 25,000 & 0 & 5,000 & 5,000 & - & - & - & - \\
\hline $\begin{array}{l}\text { Household tax } \\
\text { II. Different } \\
\text { brackets }\end{array}$ & 25,000 & & 10,000 & & 25,000 & & 25,000 & \\
\hline Individual tax & 25,000 & 0 & 5,000 & 5,000 & - & - & - & - \\
\hline Household tax & 25,000 & & 10,000 & & 10,000 & & 10,000 & \\
\hline
\end{tabular}

Clearly households 2 and 4 are treated unequally in case I, whereas households 1 and 3 are treated unequally in case II. 